Research Article

\title{
Comparison of analgesic, anti-inflammatory and anti-pyretic efficacy of diclofenac, paracetamol and their combination in experimental animals
}

\author{
Supriya D. Malhotra*, Devang A. Rana, Varsha J. Patel
}

Department of Pharmacology, Smt. NHL Municipal Medical College, Ahmedabad, Gujarat, India

Received: 8 June 2013

Accepted: 16 June 2013

\section{*Correspondence to:}

Dr. Supriya D. Malhotra,

Email:

supriyadmalhotra@gmail.com

(C) 2013 Malhotra SD et al. This is an open-access article distributed under the terms of the Creative Commons Attribution License, which permits unrestricted use, distribution, and reproduction in any medium, provided the original work is properly cited.

\begin{abstract}
Background: Various combinations of analgesics antipyretic drugs are available in the market for treatment of various musculoskeletal disorders and pain relief. Diclofenac and paracetamol combination is most commonly used combination and its rationality is questionable. The objective of this study was to compare the analgesic, anti-inflammatory and anti-pyretic activities of diclofenac, paracetamol and their combination.

Methods: Experimental animals were divided into 4 different groups - control, diclofenac, paracetamol and their combination. Analgesic activity was compared by using tail-clip method in rats and writhing test in mice, antiinflammatory activity was compared by carrageenan paw edema method using plethysmometer and anti-pyretic action was compared using TAB vaccine induced pyrexia and measuring the rectal temperature. Different doses of diclofenac $(1 \mathrm{mg} / \mathrm{kg}$ and $2 \mathrm{mg} / \mathrm{kg})$ and paracetamol $(10 \mathrm{mg} / \mathrm{kg}$ and $20 \mathrm{mg} / \mathrm{kg})$ used and same doses were used in combination group.
\end{abstract}

Results: Diclofenac sodium $(1 \mathrm{mg} / \mathrm{kg})$ showed significantly higher analgesic activity using tail-clip and writhing method compared to paracetamol $(10 \mathrm{mg} / \mathrm{kg})$ $(\mathrm{p}<0.0001)$ and the combination group $(\mathrm{p}<0.05)$. Diclofenac sodium $(2 \mathrm{mg} / \mathrm{kg})$ showed significantly higher analgesic activity using tail-clip and writhing method compared to paracetamol $(20 \mathrm{mg} / \mathrm{kg})(\mathrm{p}<0.0001)$ and the combination group $(\mathrm{p}<0.1)$. Diclofenac has no significant difference in anti-inflammatory activity using carrageenan induced paw edema when compared to the combination group $(\mathrm{p}<0.1)$ for both doses. But diclofenac when compared to paracetamol for anti-inflammatory effect, it was highly significant $(\mathrm{p}<0.0001$ and $\mathrm{p}<0.0004)$ for both doses at $1^{\text {st }}$ and $3^{\text {rd }}$ hour. Paracetamol $20 \mathrm{mg} / \mathrm{kg}$ was superior antipyretic $(\mathrm{p}<0.05,0.01$ and 0.01 ) when compared to the combination group at $1 \mathrm{hr}, 2 \mathrm{hr}$ and $3 \mathrm{hr}$ duration after injecting TAB vaccine.

Conclusion: Diclofenac and paracetamol combination was either equal or inferior in all three activities studied as compared to the individual drugs.

Keywords: Analgesic, Anti-inflammatory, Anti-pyretic, Combination, Diclofenac, Paracetamol

\section{INTRODUCTION}

Diclofenac and paracetamol (acetaminophen) are either pain relievers, or analgesics, and can reduce fevers. They differ in numerous ways, however, such as in their drug classification and strength. Consumers will find other differences between these drugs in their ease of access to them, and the types of side effects or warnings that accompany them. Moreover, one or the other of these medications may be a better choice for treating certain illnesses.
Paracetamol is considered to be a mild analgesic and antipyretic, or fever reducer. Diclofenac also has painrelieving and fever-reducing properties, but it belongs to a special class of drugs called non-steroidal antiinflammatory drugs (NSAIDs). This class of medicines tends to be more useful in controlling swelling from injury. Such anti-inflammatory properties are not characteristic of paracetamol.

Undoubtedly, diclofenac is considered a stronger drug than paracetamol, though strength depends at least in part 
on dosage. The relative strengths of diclofenac and paracetamol affect access to these medications. Paracetamol is widely available by itself or in combination forms for purchase by the general public. The drug is also combined with opioids in prescription pain relievers. In most countries, diclofenac isn't sold to consumers without a prescription and it is usually not combined with other medicines.

Another distinction between diclofenac and paracetamol is that they're likely to be recommended for different uses. Typically acetaminophen treats mild fevers or pain, and it might especially be recommended for people who cannot take NSAIDS due to allergy or stomach sensitivity. In contrast, conditions that might warrant treatment with diclofenac include arthritis, injuries to the muscles, dental surgery, gall bladder dysfunction, and kidney or bladder stones.

Also, differing side effects may accompany the use of diclofenac and paracetamol. Diclofenac may cause mild to major stomach upset, is more likely to result in allergy, and can seriously irritate the stomach lining and result in ulcers over time. The biggest concern with acetaminophen is that overdose or persistent use of the drug with alcohol may result in irreparable liver damage.

Some other variations between diclofenac and paracetamol are worth mentioning. Paracetamol is more likely to be employed for minor, "first-aid" conditions and would probably be more commonly used to treat fevers. It's also often much less expensive than diclofenac. Both drugs come with warnings about appropriate use, but in the case of diclofenac, physician guidance is also given during use because it is prescribed. Neither drug is "better" than the other, but advice from a physician may guide people toward the best choice for a specific medical condition.

World Health Organization (WHO) has suggested a pain management protocol which states that simple analgesics should be selected first and in case the patient does not respond to that, one can choose any other nonsteroidal anti-inflammatory drug (NSAID) and thereafter give a combination of NSAID with opioid analgesic. There is no place for fixed dose combination (FDC) of two NSAIDs in it. Currently FDC of diclofenac with paracetamol are available in Indian market and are widely used for pain relief. $^{1,2}$

A combination of analgesics from different classes may provide additive analgesic effects with fewer side effects than when a single therapeutic drug is used. There has been a trend over recent years for combining Diclofenac with paracetamol for the management of various conditions i.e. due to analgesic, anti-inflammatory and anti-pyretic effect. However the results of previous study remained controversial. ${ }^{3,4}$ The main reasons for developing combination analgesics are to gain efficacy and to reduce toxicity.

The combination of non-steroidal anti-inflammatory drugs is widely used in practice. There is no good clinical and experimental data to suggest combination is beneficial.

This experimental study was done to evaluate and compare the effects of diclofenac and paracetamol and its combination on analgesic, anti-inflammatory and antipyretic efficacy.

\section{METHODS}

The study was carried out after obtaining approval from Institutional Animal Ethics Committee. Albino mice of either sex weighing 20-25gm and wistar rats weighing 100-150gm were used.

The animals were housed in standard metal cages, 12 hour light/dark cycle and provided with food and water ad-libitum. The animals were fasted overnight before experiments but there was free access to drinking water. We used appropriate number of animals in each group for each different test method. In each test we used test and control groups. Diclofenac sodium $(1 \mathrm{mg} / \mathrm{kg}$ and $2 \mathrm{mg} / \mathrm{kg}$ ), paracetamol $(10 \mathrm{mg} / \mathrm{kg}$ and $20 \mathrm{mg} / \mathrm{kg})$ and their combination were administered in the ratio of $1: 10$ by oral feeding tube. The doses were calculated on the basis of $\mathrm{mg} / \mathrm{kg}$ weight of the respective of each animal. Since drugs we used were insoluble in water a suspension was prepared in $1 \%$ tragacanth. The control group received $0.5 \mathrm{ml}$ of $1 \%$ tragacanth suspension orally. Different methods used to evaluate analgesic, anti-inflammatory and anti-pyretic efficacy are shown in Table 1. For analgesic activity the established Tail-clip method (Bianchi \& Franceschini) (1954) ${ }^{7}$ and Writhing induced by chemical method (acetic-acid) of Witkin et al $(1961)^{8}$ was used.

For anti-inflammatory activity carrageenan induced rat paw method of Winter et al (1962) ${ }^{9}$ was used.

For anti-pyretic activity we used $\mathrm{TAB}$ vaccine induced pyrexia, method of Dange et al (1985). ${ }^{10}$ In our study we used the same species used by the inventor of the different method

\section{Statistical Analyses}

All results were recorded as mean \pm SEM of the duration of analgesia, anti-inflammatory and antipyretic effect. Unpaired ' $t$ ' test was used to find the significance of difference in the means of control and experimental group. $\mathrm{P}$ value less than 0.05 was considered statistically significant. We calculated the sample size as a function of effect size $\mathrm{D}^{\mathrm{a}}$ for a two-sample t-test comparison assuming a significance level of $5 \%$, a power of $90 \%$, and a two-sided test. ${ }^{11}$ 


\section{RESULTS}

Analgesic efficacy was compared using tail-clip method between the three groups. Duration of analgesia is shown in Table 2. Percentage decrease in number of wriths is shown in Figure 1. Percentage protection by acetic acid induced writhing is shown in Table 3.

Table 1: Different rodent model to evaluate analgesic, anti-inflammatory and anti-pyretic efficacy.

\begin{tabular}{|c|c|c|}
\hline Method & End-point & $\begin{array}{l}\text { No. of } \\
\text { animal in } \\
\text { each group }\end{array}$ \\
\hline \multicolumn{3}{|l|}{ Analgesic effect } \\
\hline $\begin{array}{l}\text { Tail-clip method by } \\
\text { Bianchi \& } \\
\text { Franceschini } \\
(1954)^{7}\end{array}$ & $\begin{array}{l}\text { Duration for } \\
\text { attempt to } \\
\text { remove the clip }\end{array}$ & 8 mice \\
\hline $\begin{array}{l}3 \% \text { aqueous acetic } \\
\text { acid induced } \\
\text { Writhing method of } \\
\text { Witkin et. al. } \\
(1961)^{8}\end{array}$ & $\begin{array}{l}\text { Stretch, torsion } \\
\text { to one side, } \\
\text { drawing up of a } \\
\text { hind leg, } \\
\text { retraction of the } \\
\text { abdomen and } \\
\text { opisthotonus }\end{array}$ & 8 mice \\
\hline \multicolumn{3}{|c|}{ Anti-inflammatory effect } \\
\hline $\begin{array}{l}\text { Rat paw oedema } \\
\text { induced by } \\
\text { carrageenan method } \\
\text { of Winter et. al. } \\
(1962)^{9}(0.1 \mathrm{ml} \text { of } \\
1 \%)\end{array}$ & $\begin{array}{l}\text { Volume } \\
\text { measurement } \\
\text { by } \\
\text { plethysmograph }\end{array}$ & 6 rats \\
\hline \multicolumn{3}{|l|}{ Antipyretic effect } \\
\hline $\begin{array}{l}\text { Pyrexia induced by } \\
\text { TAB Vaccine } \\
(0.1 \mathrm{ml} / 100 \mathrm{G}) \\
\text { method of Dange et. } \\
\text { al. }(1985)^{10}\end{array}$ & $\begin{array}{l}\text { Rectal } \\
\text { temperature by } \\
\text { telethermometer }\end{array}$ & 6 rats \\
\hline
\end{tabular}

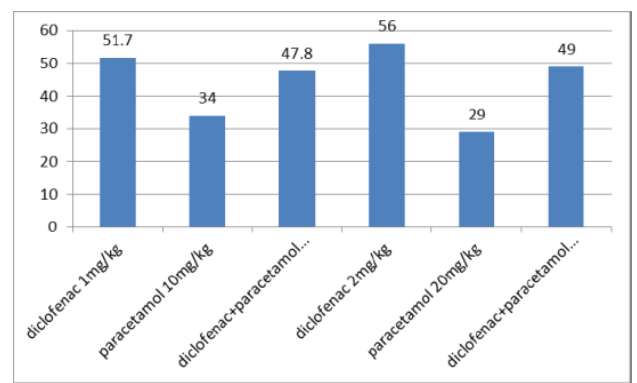

Figure 1: Percentage decrease in the number of wriths over a 20 minutes induced by acetic acid by diclofenac, paracetamol and the combination.

Comparison of anti-inflammatory efficacy between the three drug groups using rat paw edema is seen in Table 4. Effect of drug on rat paw edema at $1 \mathrm{hr}$ and $3 \mathrm{hr}$ is shown in Figure 2 and Figure 3 respectively.

Comparison of efficacy of drug groups on Tab vaccine induced pyrexia is shown in Table 5 and Figure 4.

\section{DISCUSSION}

The fixed dose combination of diclofenac and paracetamol $(50 \mathrm{mg}$ and $500 \mathrm{mg}$ respectively) is extensively prescribed medicament for a variety of musculoskeletal disorders in India. This combination appears to be promoted exclusively in India. ${ }^{12}$

Various experimental and clinical studies have been carried out on fixed dose drug combination of ibuprofen and paracetamol declaring it as illogical or irrational. ${ }^{13}$

In the present study the fixed dose combination of diclofenac sodium and paracetamol is studied with respect to its analgesic, anti-inflammatory and antipyretic activities. The results were compared to individual drugs alone, the dose ratio selected was 1:10 for diclofenac, and paracetamol, the same as found in market preparations.

Table 2: Comparison of duration of analgesia by using tail-clip method in three groups $(n=8)$.

\begin{tabular}{|lllll|}
\hline Sr. no & Drug & Dose $(\mathrm{mg} / \mathrm{kg})$ & $\begin{array}{l}\text { Duration of analgesia } \\
\text { in minutes }\end{array}$ & $\begin{array}{l}\text { P value as compared to } \\
\text { combination }\end{array}$ \\
\hline 1 & Diclofenac & 1 & $255 \pm 13.9$ & $<0.05$ \\
\hline 2 & Paracetamol & 10 & $112.5 \pm 10.9$ & $<0.001$ \\
\hline 3 & Diclofenac+Paracetamol & $1+10$ & $315 \pm 19.6$ & - \\
\hline 4 & Diclofenac & 2 & $307 \pm 9.4$ & $<0.1$ \\
\hline 5 & Paracetamol & 20 & $131 \pm 5.5$ & $<0.001$ \\
\hline 6 & Diclofenac+Paracetamol & $2+20$ & $303.7 \pm 23.04$ & - \\
\hline
\end{tabular}


Table 3: Comparison of percentage protection by using acetic acid induced writhing method in three groups.

\begin{tabular}{|c|c|c|c|c|c|c|c|}
\hline $\begin{array}{l}\text { Sr. } \\
\text { no }\end{array}$ & Drug & Group & $\begin{array}{l}\text { Dose } \\
(\mathrm{mg} / \mathrm{kg})\end{array}$ & $\begin{array}{l}\text { No. of } \\
\text { writhings }\end{array}$ & $\begin{array}{l}\% \\
\text { protection }\end{array}$ & $\begin{array}{l}\text { P value as } \\
\text { compared to } \\
\text { control }\end{array}$ & $\begin{array}{l}\text { P value as } \\
\text { compared to } \\
\text { combination }\end{array}$ \\
\hline \multirow{2}{*}{1} & \multirow{2}{*}{ Diclofenac } & Control & - & $66.12 \pm 3.47$ & \multirow{2}{*}{$51.7 \%$} & \multirow{2}{*}{$<0.001$} & \multirow{2}{*}{$<0.05$} \\
\hline & & Test & 1 & $32 \pm 2.44$ & & & \\
\hline \multirow{2}{*}{2} & \multirow{2}{*}{ Paracetamol } & Control & - & $66.12 \pm 3.47$ & \multirow{2}{*}{$34 \%$} & \multirow{2}{*}{$<0.01$} & \multirow{2}{*}{$<0.1$} \\
\hline & & Test & 10 & $43.6 \pm 3.36$ & & & \\
\hline \multirow{2}{*}{3} & \multirow{2}{*}{$\begin{array}{l}\text { Diclofenac + } \\
\text { Paracetamol }\end{array}$} & Control & - & $66.12 \pm 3.47$ & \multirow{2}{*}{$47.8 \%$} & \multirow{2}{*}{$<0.001$} & \multirow{2}{*}{-} \\
\hline & & Test & $1+10$ & $40.5 \pm 2.76$ & & & \\
\hline \multirow{2}{*}{4} & \multirow{2}{*}{ Diclofenac } & Control & - & $66.12 \pm 3.47$ & \multirow{2}{*}{$56 \%$} & \multirow{2}{*}{$<0.001$} & \multirow{2}{*}{$<0.1$} \\
\hline & & Test & 2 & $29.12 \pm 3.21$ & & & \\
\hline \multirow{2}{*}{5} & \multirow{2}{*}{ Paracetamol } & Control & - & $66.12 \pm 3.47$ & \multirow{2}{*}{$29 \%$} & \multirow{2}{*}{$<0.01$} & \multirow{2}{*}{$<0.01$} \\
\hline & & Test & 20 & $47.3 \pm 3.4$ & & & \\
\hline \multirow{2}{*}{6} & \multirow{2}{*}{$\begin{array}{l}\text { Diclofenac+ } \\
\text { Paracetamol }\end{array}$} & Control & - & $66.12 \pm 3.47$ & \multirow{2}{*}{$49 \%$} & \multirow{2}{*}{$<0.001$} & \multirow{2}{*}{-} \\
\hline & & Test & $2+20$ & $34.3 \pm 3.09$ & & & \\
\hline
\end{tabular}

Table 4: Anti-inflammatory effect produced by diclofenac, paracetamol with fixed dose combination of diclofenac and paracetamol by carrageenan induced rat paw edema.

\begin{tabular}{|c|c|c|c|c|c|c|c|c|c|c|c|}
\hline \multirow{2}{*}{$\begin{array}{l}\text { Sr. } \\
\text { no }\end{array}$} & \multirow[t]{2}{*}{ Drug } & \multirow[t]{2}{*}{ Group } & \multirow{2}{*}{$\begin{array}{l}\text { Dose } \\
\text { (mg/ } \\
\text { kg) } \\
\text { p.o. }\end{array}$} & \multicolumn{2}{|c|}{$\begin{array}{l}\text { Paw volume } \\
\text { (Mean } \pm \text { SEM) }\end{array}$} & \multicolumn{2}{|c|}{$\%$ inhibition } & \multicolumn{2}{|c|}{$\begin{array}{l}\text { P value as } \\
\text { compared to } \\
\text { control }\end{array}$} & \multicolumn{2}{|c|}{$\begin{array}{l}P \text { value as } \\
\text { compared to } \\
\text { combination }\end{array}$} \\
\hline & & & & $1^{\text {st }} \mathrm{hr}$ & $3^{\mathrm{rd}} \mathrm{hr}$ & $1^{\text {st }} \mathrm{hr}$ & $\begin{array}{l}3^{\text {rd }} \\
\text { hr }\end{array}$ & $\mathbf{1}^{\text {st }} \mathbf{h r}$ & $3^{\text {rd } h r}$ & $1^{\text {st }} \mathrm{hr}$ & $3^{\text {rd } h r}$ \\
\hline \multirow{2}{*}{1} & \multirow{2}{*}{ Diclofenac } & Control & - & $\begin{array}{l}0.51 \pm \\
0.06\end{array}$ & $\begin{array}{l}0.59 \pm \\
0.04\end{array}$ & \multirow{2}{*}{48.8} & \multirow{2}{*}{79.4} & \multirow{2}{*}{$<0.001$} & \multirow{2}{*}{$<0.001$} & \multirow{2}{*}{$<0.1$} & \multirow{2}{*}{$<0.1$} \\
\hline & & Test & 1 & $\begin{array}{l}0.25 \pm 0 . \\
02\end{array}$ & $\begin{array}{l}0.12 \pm \\
0.01\end{array}$ & & & & & & \\
\hline \multirow{2}{*}{2} & \multirow{2}{*}{ Paracetamol } & Control & - & $\begin{array}{l}0.51 \pm \\
0.06\end{array}$ & $\begin{array}{l}0.59 \pm \\
0.04\end{array}$ & \multirow{2}{*}{18.0} & \multirow{2}{*}{44.7} & \multirow{2}{*}{$<0.01$} & \multirow{2}{*}{$<0.01$} & \multirow{2}{*}{$<0.01$} & \multirow{2}{*}{$<0.01$} \\
\hline & & Test & 10 & $\begin{array}{l}0.42 \pm \\
0.07\end{array}$ & $\begin{array}{l}0.32 \pm \\
0.06\end{array}$ & & & & & & \\
\hline \multirow{2}{*}{3} & \multirow{2}{*}{$\begin{array}{l}\text { Diclofenac + } \\
\text { Paracetamol }\end{array}$} & Control & - & $\begin{array}{l}0.51 \pm \\
0.06\end{array}$ & $\begin{array}{l}0.59 \pm \\
0.04\end{array}$ & \multirow{2}{*}{45.0} & \multirow{2}{*}{76.0} & \multirow{2}{*}{$<0.001$} & \multirow{2}{*}{$<0.001$} & \multirow{2}{*}{-} & \multirow{2}{*}{-} \\
\hline & & Test & $1+10$ & $\begin{array}{l}0.29 \pm \\
0.02\end{array}$ & $\begin{array}{l}0.14 \pm \\
0.02\end{array}$ & & & & & & \\
\hline \multirow{2}{*}{4} & \multirow{2}{*}{ Diclofenac } & Control & - & $\begin{array}{l}0.49 \pm \\
0.09\end{array}$ & $\begin{array}{l}0.51 \pm \\
0.11\end{array}$ & \multirow{2}{*}{57.0} & \multirow{2}{*}{86.0} & $<0 \Omega 01$ & & $<01$ & $\leq 01$ \\
\hline & & Test & 2 & $\begin{array}{l}0.21 \pm \\
0.06\end{array}$ & $\begin{array}{l}0.04 \pm \\
0.07\end{array}$ & & & $<0.001$ & $<0.001$ & $<0.1$ & $<0.1$ \\
\hline & & Control & - & $\begin{array}{l}0.49 \pm \\
0.09\end{array}$ & $\begin{array}{l}0.51 \pm \\
0.11\end{array}$ & & & & & & \\
\hline 5 & Paracetamol & Test & 20 & $\begin{array}{l}0.37 \pm \\
0.0\end{array}$ & $\begin{array}{l}0.27 \pm \\
0.12\end{array}$ & 24.3 & 46.0 & $<0.01$ & $<0.02$ & $<0.01$ & $<0.001$ \\
\hline 6 & Diclofenac+ & Control & - & $\begin{array}{l}0.49 \pm \\
0.09 \\
\end{array}$ & $\begin{array}{l}0.51 \pm \\
0.12 \\
\end{array}$ & & & & & & \\
\hline 6 & Paracetamol & Test & $2+20$ & $\begin{array}{l}0.22 \pm \\
0.04\end{array}$ & $\begin{array}{l}0.07 \pm \\
0.01\end{array}$ & 53.0 & 85.4 & $<0.001$ & $<0.001$ & - & - \\
\hline
\end{tabular}




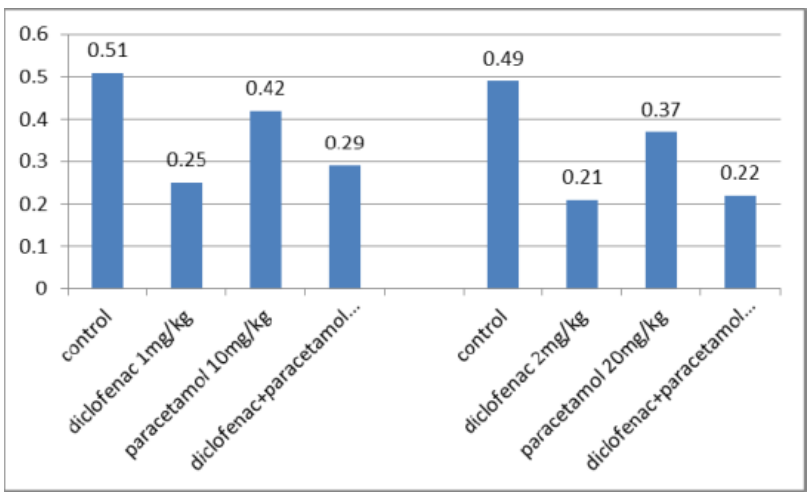

Figure 2: Effect of diclofenac, paracetamol and fixed dose combination of diclofenac and paracetamol carrageenan induced paw edema at $1 \mathrm{hr}$.

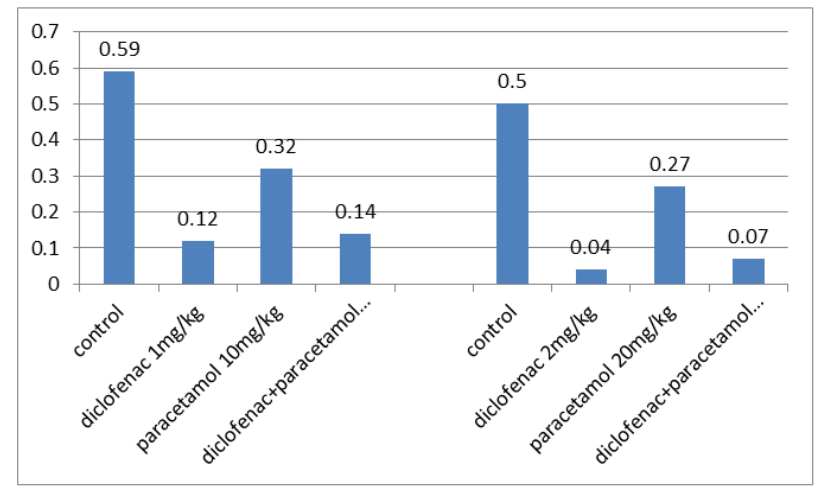

Figure 3: Effect of diclofenac, paracetamol and fixed dose combination of diclofenac and paracetamol on carrageenan induced paw edema at $3 \mathrm{hr}$.

Table 5: Antipyretic activity of diclofenac, paracetamol and fixed dose combination of diclofenac and paracetamol on TAB vaccine induced pyrexia.

\begin{tabular}{|c|c|c|c|c|c|c|c|c|c|c|}
\hline \multirow{2}{*}{ Drug mg/kg } & \multirow{2}{*}{$\begin{array}{l}\text { Before } \\
\text { TAB } \\
\text { inj i.p. } \\
\left({ }^{0} \mathrm{~F}\right)\end{array}$} & \multirow{2}{*}{$\begin{array}{l}\text { After } \\
\text { TAB inj } \\
\text { i.p. }\left({ }^{0} \mathbf{F}\right)\end{array}$} & \multicolumn{4}{|c|}{$\begin{array}{l}\text { Rectal temp }{ }^{0} \mathrm{~F} \text { after drug treatment (hrs) } \\
\text { mean } \pm \text { SEM }\end{array}$} & \multirow{2}{*}{$\begin{array}{l}\text { P value } \\
\text { compared } \\
\text { to control } \\
\text { at } 4 \mathrm{hrs}\end{array}$} & \multicolumn{3}{|c|}{$\begin{array}{l}P \text { value compared to } D+P \\
\text { at } 4 \text { hrs }\end{array}$} \\
\hline & & & 1 & 2 & 3 & 4 & & 1 & 2 & 3 \\
\hline Control & $\begin{array}{l}97.17 \pm \\
0.06\end{array}$ & $\begin{array}{l}99.73 \pm \\
0.07\end{array}$ & $\begin{array}{l}99.72 \pm \\
0.07\end{array}$ & $\begin{array}{l}99.49 \pm \\
0.58\end{array}$ & $\begin{array}{l}99.46 \pm \\
0.08\end{array}$ & $\begin{array}{l}99.41 \pm \\
0.03\end{array}$ & $<0.001$ & - & - & - \\
\hline $\begin{array}{l}\text { Diclofenac } \\
2 \mathrm{mg} / \mathrm{kg}\end{array}$ & $\begin{array}{l}97.50 \pm \\
0.83\end{array}$ & $\begin{array}{l}99.4 \pm \\
0.15\end{array}$ & $\begin{array}{l}99.02 \pm \\
-0.6 \\
0.38\end{array}$ & $\begin{array}{l}98.57 \pm \\
0.09 \\
0.45\end{array}$ & $\begin{array}{l}98.28 \pm \\
0.06\end{array}$ & $\begin{array}{l}98.01 \pm \\
0.10\end{array}$ & $<0.001$ & $<0.1$ & $<0.02$ & $<0.01$ \\
\hline $\begin{array}{l}\text { Paracetamol } \\
20 \mathrm{mg} / \mathrm{kg}\end{array}$ & $\begin{array}{l}97.42 \pm \\
0.10\end{array}$ & $\begin{array}{l}99.63 \pm \\
0.10\end{array}$ & $\begin{array}{l}98.81 \pm \\
0.13 \\
0.82 \\
\end{array}$ & $\begin{array}{l}98.51 \pm \\
0.06\end{array}$ & $\begin{array}{l}98.21 \pm \\
-0.04\end{array}$ & $\begin{array}{l}97.84 \pm \\
0.28\end{array}$ & $<0.001$ & $<0.05$ & $<0.001$ & $<0.001$ \\
\hline $\begin{array}{l}\text { Diclofenac } \\
2 \mathrm{mg} / \mathrm{kg}+ \\
\text { Paracetamol } \\
\text { 20mg/kg }\end{array}$ & $\begin{array}{l}97.48 \pm \\
0.58\end{array}$ & $\begin{array}{l}99.70 \pm \\
-0.83\end{array}$ & $\begin{array}{l}98.97 \pm \\
0.31 \\
0.73\end{array}$ & $\begin{array}{l}98.82 \pm \\
0.74\end{array}$ & $\begin{array}{l}98.52 \pm \\
-0.1\end{array}$ & $\begin{array}{l}98.39 \pm \\
0.02\end{array}$ & $<0.001$ & - & - & - \\
\hline
\end{tabular}

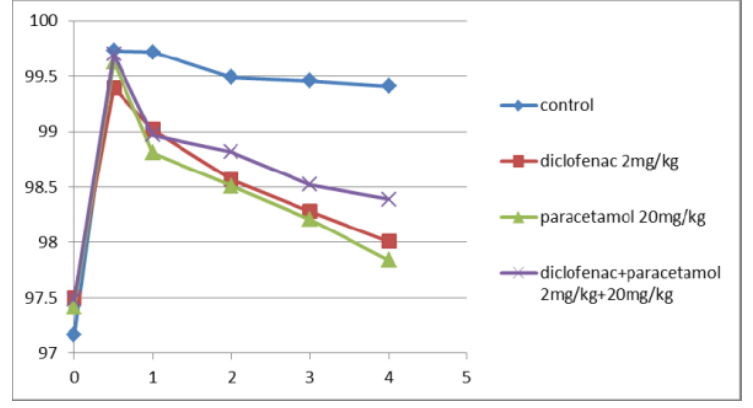

Figure 4: Time course of anti-pyresis shown by diclofenac sodium, paracetamol and the combination.

Analgesic activity was studied by two methods viz tailclip method and writhing test. Tail clip method confirmed the presence of analgesia and also gave an idea about the duration of analgesic effect, the writhing test depicted the percentage protection showed by the drug against painful stimulus i.e. intensity of analgesia.
Acetic acid writhing method has advantage that the test takes less time, effect is of short duration, rapid in onset and exposure of animals to discomfort is curtailed. Its disadvantages lie in the fact that anti-nociceptive effect can't be easily distinguished from anti-inflammatory effect. The test produces false positives. ${ }^{14}$

In the tail clip method diclofenac sodium $1 \mathrm{mg} / \mathrm{kg}$ produced analgesia or shorter duration in comparison to the combination of $1 \mathrm{mg} / \mathrm{kg}+10 \mathrm{mg} / \mathrm{kg}$ of diclofenac sodium and paracetamol respectively and the difference was statistically significant $(\mathrm{p}<0.05)$. Diclofenac sodium in a higher dose of $2 \mathrm{mg} / \mathrm{kg}$ when compared to the combination of $2 \mathrm{mg} / \mathrm{kg}$ of diclofenac and $20 \mathrm{mg} / \mathrm{kg}$ of paracetamol the difference in the duration of analgesia was not statistically significant $(\mathrm{p}>0.05)$.

In the writhing test, diclofenac $1 \mathrm{mg} / \mathrm{kg}$ was superior to the combination of $(1 \mathrm{mg} / \mathrm{kg}$ and $10 \mathrm{mg} / \mathrm{kg})$ of diclofenac and paracetamol (where percentage inhibition or wriths 
were concerned) and the difference was statistically significant $(\mathrm{p}<0.05)$. in comparison with diclofenac $2 \mathrm{mg} / \mathrm{kg}$, the combination $(2 \mathrm{mg} / \mathrm{kg}+20 \mathrm{mg} / \mathrm{kg})$ showed less inhibition of writhing but the difference was not statistically significant $(\mathrm{p}>0.05)$.

In both the methods, paracetamol was an inferior analgesic as compared to the combination. In tail clip method, the duration of analgesia was less as compared to the combination and the difference was highly significant $(p<0.001)$. In writhing method as compared to the combination and the difference was statistically significant $(\mathrm{p}<0.01)$.

The antinociceptive effect of diclofenac involves a central nervous component which may be elicited from several defined areas in the CNS. Part of the antinociceptive effect seems to be mediated by descending inhibitory opioid, serotonin and/or other neurotransmitter systems interfering with visceral pain impulse traffic at the spinal level. While NSAIDs and paracetamol interfere with nociception associated with spinal NMDA receptor activation. This effect involves an inhibitory action on spinal nitric oxide (NO) mechanisms. Possibly, the supraspinal antinociceptive effect of NSAIDs may be explained by an analogous action. ${ }^{15}$

Anti-inflammatory activity was evaluated by carrageenan induced rat paw edema. Carrageenan is preferred to several other inflammatory agents because the edema produced is less influenced by non-specific factors such as vasodilatation, ganglion blockade or diuresis.

Diclofenac sodium $1 \mathrm{mg} / \mathrm{kg}$ and $2 \mathrm{mg} / \mathrm{kg}$ when compared to the combination of $(1 \mathrm{mg} / \mathrm{kg}+10 \mathrm{mg} / \mathrm{kg})$ and $(2 \mathrm{mg} / \mathrm{kg}$ $+20 \mathrm{mg} / \mathrm{kg}$ ) of diclofenac and paracetamol respectively, showed no significant difference in reduction in paw edema $(p>0.05)$. This signified that the fixed dose combination is not superior to diclofenac sodium as far as anti-inflammatory effect is concerned.

Paracetamol 10mg/kg and $20 \mathrm{mg} / \mathrm{kg}$ did show significant anti-inflammatory effect as compared to control $(\mathrm{p}<0.01)$ but in comparison to the combination, paracetamol was a weaker anti-inflammatory at both the losses and the difference was also statistically significant $(\mathrm{p}<0.01)$. This weaker anti-inflammatory effect is also seen in previous two studies. ${ }^{16,17}$

Anti-pyretic activity was evaluated by injecting bacterial pyrogen (TAB vaccine) in rats. The method was selected because the mechanism of fever which develops post TAB vaccine resembles the development of fever in man. ${ }^{18}$

Also the fever does not show variation of more than $0.1^{0} \mathrm{~F}$ over a 4hours study period.

As an antipyretic, paracetamol $(20 \mathrm{mg} / \mathrm{kg})$ was a superior anti-pyretic drug was compared to both diclofenac sodium $(2 \mathrm{mg} / \mathrm{kg})$ and the combination of $(2 \mathrm{mg} / \mathrm{kg}+20 \mathrm{mg} / \mathrm{kg})$ of diclofenac and paracetamol respectively. Paracetamol had a quicker onset of action, peak antipyresis observed at hrs. and temperature almost touched the baseline normal temperature. Diclofenac sodium $(2 \mathrm{mg} / \mathrm{kg})$ did lower the temperature significantly; peak antipyresis at $4 \mathrm{hrs}$, but the temperature did not touch the baseline normal temperature. The combination also showed significant antipyresis but it was inferior to paracetamol and the difference was highly significant $(p<0.001)$ at 4 hours. Similarly, the combination was inferior to diclofenac $(2 \mathrm{mg} / \mathrm{kg})$ and the difference was statistically significant $(\mathrm{p}<0.01)$ at 4 hours.

In all the above activities there is no evidence that the combination of diclofenac sodium and paracetamol in a fixed dose ratio is superior to individual drug diclofenac in analgesia, inflammation and to paracetamol where anti-pyresis was concerned.

Since the two drugs, have a common mechanism action (COX inhibition), share the same t1/2 (1-3hrs), volume of distribution $(0.9-0.121 / \mathrm{kg})$, metabolic characteristics (glucuronide and sulphate conjugation) and identical elimination, some pharmacokinetic interactions may be expected which decrease the optimal effect of each drug. ${ }^{19}$

The results of the present study support the same. Thus the fixed dose combination of diclofenac with paracetamol is irrational as far as therapeutic efficacy is concerned. Moreover, the same identical characteristics could lead to additive side effects in the form of gastric toxicity and analgesic nephropathy. ${ }^{20,21}$

However the results of this study carried out in experimental animals cannot be extrapolated to man, only the clinical studies in form of comparative clinical trial can validate these results. For example comparisons in post-operative pain or post-episiotomy pain for analgesia, in patients of rheumatoid arthritis for anti-inflammatory effects and so on. Present study can only indicate the lack of superiority diclofenac paracetamol combination over the two drugs individually in experimental models of pain, inflammation and pyrexia.

Few systemic reviews found that the concurrent use of paracetamol and NSAIDs was superior to paracetamol alone. However, no superior analgesic effect of the combination compared with the NSAID alone was found. $^{22,23}$

Paracetamol- diclofenac appears to be best combination a similar finding to the work of Zezi and Abdulkadir where they also evaluated analgesic and anti-inflammatory efficacy using rat writhing test and hind limb paw edema model. $^{24}$

\section{CONCLUSION}

There are many combinations of analgesics anti-pyretic drugs available in the market for treatment of various musculoskeletal disorders and pain relief. The fixed dose 
combination of diclofenac and paracetamol marketed exclusively in India is one such combination, a scientific study to establish rationality and justification of such combination was needed.

The three major therapeutic activities viz. analgesic, antiinflammatory and antipyretic were studied to compare the combination with individual drugs.

The combination was either equal or inferior but not superior in all the three activities studied as compared to the individual drugs. Diclofenac sodium was superior to the combination where analgesia was concerned; it was equal to combination in inflammation. Further paracetamol was a superior antipyretic as compared to both diclofenac sodium and the combination.

In view of many similarities, which exist in mechanism of action, distribution and elimination characteristics of these two drugs, the combination is not likely to be theoretically superior.

The combination could possibly lead to addition of toxic effects including severe gastric erosions, ulcerations and bleeding. Analgesic nephropathy well documented to be caused by analgesic-antipyretic combinations cannot be overlooked.

NSAIDs could be combined with opioids in pain relief to achieve synergistic effect. NSAIDs could be coadministered with paracetamol on "as and when required basis" but not as a fixed dose combination.

Prescribing fixed dose combination of NSAIDs limit flexibility of dosing and individualization of drug therapy.

Lastly, these experimental observations need to be validated by controlled clinical studies.

\section{Funding: None}

Conflict of Interest: None Declared

Ethical approval: The study was approved by the

Institutional Animal Ethics Committee

\section{REFERENCES}

1. Yadav P, Kanase V, Lacchiramka P, Jain S. Drug utilization trends in ENT outpatient department in a Teaching hospital. Int J Pharm Biol Sci 2010;1:15360.

2. Jeevangi SR, Patil RB, Avanti S, Manjunath S, Patil B, Devi K. Drug utilization study in a burn care unit of a tertiary care hospital. Asian Pac J Trop Dis 2011;1:41-6.

3. Ong CK, Seymour RA, Lirk P, Merry AF. Combining Paracetamol (Acetaminophen) with Nonsteroidal Antiinflammatory Drugs: A Qualitative Systematic Review of Analgesic Efficacy for Acute Postoperative Pain. Anesth Analg 2010;110(4):1170-9.
4. Munishankar, Fettes P, Moore C, McLeod GA. A double-blind randomized controlled trial of paracetamol, diclofenac or the combination for pain relief after caesarean section. Int J Obstet Anesth 2008;17:9-14.

5. Beaver WT. Combination analgesics. Am J Med 1984;77:38-53.

6. J. Demeules, V. Rollason, V. Piguet, P. Dayer. Clinical Pharmacology and rationale of analgesic combinations. Eur J Anaesthesiol Suppl. 2003;28:711 .

7. Bianchi C. \& Francheschini J. Experimental observations on Haffner's method for testing analgesic drugs. Brit J Pharmacol 1954;9(3):280-4.

8. Witkin LB, Hebner CF, Gaddi F, O'Keefe E, Spitaletta P, Plumer AJ. Pharmacology of 2aminoindane hydrochloride (SU-8629): A potent non-narcotic analgesic. J Pharmacol Exp Ther. 1961;133:400-8.

9. Winter CA, Risley EA, Nuss GW. Carrageenaninduced oedema in hind paw of the rats as an assay for anti-inflammatory drugs. Proc Soc Exp Biol Med. 1962;111:544-7.

10. Dange SV, Shah KU, Ghongane BB, Ranade RS. Potentiation of antipyretic effect of acetaminophen by concomitant administration of ascorbic acid. Indian J Physiol Pharmacol. 1985 AprJun;29(2):129-31.

11. Festing MF and Altman DG.Guidelines for the Design and Statistical Analysis of Experiments Using Laboratory Animals. ILAR J. 2002;43(4):244-58.

12. Dahanukar SA, Regs N N. Focus on NSAID combinations. The Indian Practitioner 1998;51(1):43-7.

13. Bhattacharya SK, Goel RK, Bhattacharya SK, Tandon R. Potentiation of gastric toxicity of ibuprofen by paracetamol in the rat. J Pharm Pharmacol 1991;43(7):520-1.

14. H O Collier, L C Dinneen, C A Johnson, and C Schneider. The abdominal constriction response and its suppression by analgesic drugs in the mouse. $\mathrm{Br} \mathrm{J}$ Pharmacol Chemother. 1968 February; 32(2): 295310.

15. Björkman R. Central antinociceptive effects of nonsteroidal anti-inflammatory drugs and paracetamol. Experimental studies in the rat. Acta Anaesthesiologica Scandinavica. Supplementum 1995;103:1-44.

16. Seegers AJM, Jager LP, Zandberg P, van Noordwijk J. The anti-inflammatory, analgesic and antipyretic activities of non-narcotic analgesic drug mixtures in rats. Arch Int Pharmacodyn Ther 1981;251:237-54.

17. Flower R, Gryglewski R, Herbaczyńska-Cedro K, Vane JR. Effects of anti-inflammatory drugs on prostaglandin biosynthesis. Nat New Biol 1972;238:104-6.

18. Feldberg W, Saxena PN. Prostaglandins, endotoxin and lipid A on body temperature in rats. J Physiol 1975;249:601-15. 
19. Levi S, Shaw-Smith C. Non-steroidal antiinflammatory drugs: how do they damage the gut? Br J Rheumatol. 1994;33(7):605-12.

20. Duggin GG. Combination analgesic-induced kidney disease: the Australian experience. Am J Kidney Dis. 1996 Jul;28(1 Suppl 1):S39-47.

21. Radford MG Jr, Holley KE, Grande JP, Larson TS, Wagoner RD, Donadio JV, McCarthy JT. Reversible membranous nephropathy associated with the use of nonsteroidal anti-inflammatory drugs. JAMA 1996 Aug 14;276(6):466-9.

22. Rømsing J, Møiniche S, Dahl JB. Rectal and parenteral paracetamol and paracetamol in combination with NSAIDs, for postoperative analgesia. Br J Anaesth. 2002 Feb;88(2):215-26.

23. Hyllested M, Jones S, Pedersen JL, Kehlet $\mathrm{H}$. Comparative effect of paracetamol, NSAIDs or their combination in postoperative pain management: a qualitative review. $\mathrm{Br}$ J Anaesth. 2002 Feb;88(2):199-214.

24. Zezi, Abdulkadir Umar. Some pharmacological studies of paracetamol and paracetamol coformulated with either aspirin, caffeine, diclofenac or ibuprofen. Jun-2006 [dissertation]. Available at http://kubanni.abu.edu.ng:8080/jspui/handle/123456 789/1798. Accessed 14 January 2013.

doi:10.5455/2319-2003.ijbcp20130821

Cite this article as: Malhotra SD, Rana DA, Patel VJ. Comparison of analgesic, anti-inflammatory and antipyretic efficacy of diclofenac, paracetamol and their combination in experimental animals. Int J Basic Clin Pharmacol 2013;2:458-65. 